\title{
Toxic Compound, Anti-Nutritional Factors and Functional Properties of Protein Isolated from Detoxified Jatropha curcas Seed Cake
}

\section{Donlaporn Saetae and Worapot Suntornsuk *}

Department of Microbiology, Faculty of Science, King Mongkut's University of Technology Thonburi, Bangkok 10140, Thailand; E-Mail: sdonlaporn@yahoo.com

* Author to whom correspondence should be addressed; E-Mail: worapot.sun@kmutt.ac.th; Tel.: +662-470-8890; Fax: +662-470-8891.

Received: 24 November 2010; in revised form: 3 December 2010 / Accepted: 23 December 2010 / Published: 28 December 2010

\begin{abstract}
Jatropha curcas is a multipurpose tree, which has potential as an alternative source for biodiesel. All of its parts can also be used for human food, animal feed, fertilizer, fuel and traditional medicine. J. curcas seed cake is a low-value by-product obtained from biodiesel production. The seed cake, however, has a high amount of protein, with the presence of a main toxic compound: phorbol esters as well as anti-nutritional factors: trypsin inhibitors, phytic acid, lectin and saponin. The objective of this work was to detoxify $J$. curcas seed cake and study the toxin, anti-nutritional factors and also functional properties of the protein isolated from the detoxified seed cake. The yield of protein isolate was approximately $70.9 \%$. The protein isolate was obtained without a detectable level of phorbol esters. The solubility of the protein isolate was maximal at $\mathrm{pH} 12.0$ and minimal at $\mathrm{pH}$ 4.0. The water and oil binding capacities of the protein isolate were $1.76 \mathrm{~g}$ water/g protein and $1.07 \mathrm{~mL}$ oil/g protein, respectively. The foam capacity and stability, including emulsion activity and stability of protein isolate, had higher values in a range of basic $\mathrm{pHs}$, while foam and emulsion stabilities decreased with increasing time. The results suggest that the detoxified J. curcas seed cake has potential to be exploited as a novel source of functional protein for food applications.
\end{abstract}

Keywords: Jatropha curcas; protein isolate; functional properties; anti-nutritional factors 


\section{Introduction}

Jatropha curcas is a multipurpose plant which belongs to the Euphorbiaceae family. It is thought to be native to Central and South America and widely distributed in Central America, Africa and Asia. Recently, it has been widely planted in Thailand and promoted as a biodiesel plant. Its seed contains $60-66 \%$ crude lipid and 30-32\% crude protein [1]. Increasing J. curcas production as a biofuel source will increase the quantity of its seed cake, which is a by-product. The seed cake left after extraction of oil provides a high amount of protein [2] and all concentrations of essential amino acids except lysine are higher than those of the Food and Agriculture Organization (FAO) reference pattern suggested for pre-school children [3]. However, major constituents contained in the seed cake are toxic compound and anti-nutritional factors. The main toxic component of the seed cake is phorbol esters and the anti-nutritional factors found in the seed cake are trypsin inhibitor, phytic acid, lectin and saponin.

Phorbol esters have been classified as the main toxic agents in J. curcas seed cake responsible for toxicity [4]. The toxicity of phorbol esters limits the use of J. curcas seed cake as a human or animal food. The phorbol esters affect humans and animals by causing tumor promotion, cell proliferation, blood platelet activation, lymphocyte mitogenesis, erythema of the skin, prostaglandin production and stimulation of degranulation in neutrophils [5]. If the phorbol esters were removed, the J. curcas seed cake could be a protein-rich ingredient in food or feed diets and would also provide a valuable protein.

Plant protein isolates are important ingredients for protein sources in human and animal feed. The protein isolation generally consists of two steps, which are protein solubilization in alkaline solution and protein precipitation. For plant protein precipitation, acid precipitation at the isoelectric $\mathrm{pH}$ is the general method used. Since plant protein isolates are less expensive sources than animal ones, they are used to fortify, formulate and apply food products with desirable functional properties. Important functional properties required in protein ingredients include solubility, water and oil binding capacities, emulsion activity and stability and also foam capacity and stability. The present study focused on the toxin, anti-nutritional factors and functional properties of protein isolated from detoxified J. curcas seed cake.

\section{Results and Discussion}

\subsection{Chemical Compositions}

The chemical composition of $J$. curcas seed cake, detoxified seed cake and protein isolated from the detoxified seed cake are shown in Table 1. The protein content of both $J$. curcas seed cake and detoxified seed cake were similar, approximately 23\%, suggesting that the ethanol extraction did not affect the protein content; the protein contents were also similar to that reported by Makkar et al. [6]. However, the other chemical compositions of both seed cakes, especially fat and fiber, were considerably different, as indicated in Table 1, since ethanol extraction heavily affected fat and fiber. The yield of proteins isolated from the detoxified seed cake was approximately $70.9 \%$, which is similar to that reported by Devappa and Swamylingappa [7]. The protein content of the protein isolate (89.0\%) was approximately four-fold higher than that of the detoxified seed cake. Color of the protein isolate was found to be brownish, partly resulting from the dark color of the J. curcas seed shells. Its color characteristic agreed well with the reports of Saetae et al. [8] and Devappa and Swamylingappa [7]. 
Table 1. Chemical compositions of $J$. curcas seed cake, detoxified seed cake and its protein isolate (on dry matter basis).

\begin{tabular}{lccc}
\hline $\begin{array}{c}\text { Composition } \\
(\boldsymbol{\%}, \mathbf{w} / \mathbf{w})\end{array}$ & $\begin{array}{c}\text { J. curcas } \\
\text { Seed Cake }\end{array}$ & $\begin{array}{c}\text { Detoxified } \boldsymbol{J} \text {. curcas } \\
\text { Seed Cake }\end{array}$ & $\begin{array}{c}\text { Detoxified Seed Cake } \\
\text { Protein Isolate }^{\mathbf{1}}\end{array}$ \\
\hline Crude fat & $14.8 \pm 0.5$ & $8.6 \pm 1.6$ & $7.1 \pm 0.4$ \\
Crude fiber & $11.0 \pm 1.7$ & $8.2 \pm 0.3$ & $0.7 \pm 0.1$ \\
Crude ash & $7.8 \pm 0.1$ & $6.4 \pm 0.2$ & $1.8 \pm 0.1$ \\
Crude protein & $23.5 \pm 1.5$ & $23.0 \pm 1.0$ & $89.0 \pm 1.8$ \\
Available & 42.9 & 53.8 & 1.4 \\
Carbohydrate & & 5 & \\
\hline
\end{tabular}

${ }^{1}$ Means \pm standard deviation of triplicate determinations; ${ }^{2}$ Saetae et al. [8].

\subsection{Toxic Compound and Anti-Nutritional Factors}

The contents of toxin and anti-nutritional factors detected in $J$. curcas seed cake, detoxified J. curcas seed cake and its protein isolate are presented in Table 2. The results show that the phorbol ester and lectin contents were not detected in the detoxified $J$. curcas seed cake, whereas they were observed in high levels in J. curcas seed cake. Phytic acid, trypsin inhibitor and saponin found in the detoxified seed cake were also much lower than those found in J. curcas seed cake. This suggests that ethanol extraction could be an effective method to completely remove the phorbol esters and lectin and partially remove the phytic acid, trypsin inhibitor and saponin from the seed cake.

No phorbol esters and lectin were found in the protein isolated from the detoxified seed cake (Table 2). The phytic acid detected in the protein isolate was $0.03 \%$, which was much lower than that of the detoxified seed cake. This result implies that the phytic acid content in the protein isolate was reduced by $98 \%$ from the seed cake. This might be due to the protein isolation process resulting in binding of phytate ions to sodium ions in alkali solution. Similar observations were reported in several works $[7,9,10]$. The trypsin inhibitor level of the protein isolate was approximately eight-fold higher than that of the detoxified seed cake. Makkar et al. [6] also reported that the trypsin inhibitor detected in $J$. curcas protein concentrate was approximately 10-fold higher than that of the seed cake. This result indicates that the trypsin inhibitor was solubilized and precipitated at the same $\mathrm{pH}$ as other proteins so that it was found in high level in the protein isolate. The saponin content of the protein isolate was found in a very low level. It was decreased by approximately $80 \%$ from the seed cake. This suggests that the saponin was partially removed by protein isolation as mentioned in several reports $[7,9,10]$. 
Table 2. Toxic compound and anti-nutritional factors in $J$. curcas seed cake, detoxified seed cake and its protein isolate.

\begin{tabular}{|c|c|c|c|}
\hline Component & $\begin{array}{c}\text { J. curcas } \\
\text { Seed Cake } \\
\end{array}$ & $\begin{array}{c}\text { Detoxified } J . \text { curcas }^{\text {curca }} \\
\text { Seed Cake } \\
\end{array}$ & $\begin{array}{c}\text { Detoxified Seed Cake } \\
\text { Protein Isolate } \\
\end{array}$ \\
\hline $\begin{array}{l}\text { Phorbol esters } \\
(\mathrm{mg} / \mathrm{g} \text { dry sample })^{\mathrm{a}}\end{array}$ & $0.73 \pm 0.06$ & $\mathrm{ND}^{3}$ & $\mathrm{ND}^{3}$ \\
\hline $\begin{array}{l}\text { Phytic acid } \\
(\%, w / w)\end{array}$ & $8.55 \pm 0.51$ & $1.87 \pm 0.11$ & $0.03 \pm 0.00$ \\
\hline $\begin{array}{l}\text { Trypsin inhibitor } \\
\text { (TIU } / g \text { dry } \\
\text { sample) }\end{array}$ & $7.42 \pm 1.64$ & $1.12 \pm 0.09$ & $8.36 \pm 0.03$ \\
\hline $\begin{array}{l}\text { Lectin activity } \\
\text { (HU } / \mathrm{mg} \text { protein) }\end{array}$ & $13.15 \pm 0.45$ & $\mathrm{ND}^{3}$ & $\mathrm{ND}^{3}$ \\
\hline $\begin{array}{l}\text { Saponin } \mathrm{d} \\
(\mu \mathrm{g} / \mathrm{g} \text { dry sample })\end{array}$ & $27.82 \pm 0.68$ & $10.04 \pm 0.60$ & $2.04 \pm 0.01$ \\
\hline
\end{tabular}

\subsection{Functional Properties of Protein Isolate}

\subsubsection{Solubility}

The solubility of proteins isolated from the detoxified seed cake as a function of $\mathrm{pH}$ in a range of 2.0 to 12.0 is illustrated in Figure 1. High solubility of protein is an important characteristic and is required for protein isolates to be applied as functional ingredients in foods [11]. The $\mathrm{pH}$ is an important factor since it affects the protein solubility. The solubility of the protein isolate observed in this study followed a U-shape curve, which is typically found in general legume seed proteins. The solubility of the protein isolate was low at acidic $\mathrm{pH}$ condition and increased with increasing $\mathrm{pH}$ values. The solubility was minimal at $\mathrm{pH} 4.0$, indicating its isoelectric point. Similar observations were reported by Makkar et al. [6], Saetae et al. [8], Vani and Zayas [12] and Mohamed et al. [13]. At the isoelectric point, the net charge of protein molecules is zero and the protein itself is precipitated. The maximum solubility of protein isolate was reached at $\mathrm{pH}$ 12.0. The results suggest that the protein isolate had good solubility under basic conditions.

\subsubsection{Water and Oil Binding Capacities}

Water binding capacity of proteins is important in viscous foods in order to provide body, thickening and viscosity. The water binding capacity of the protein isolated from the detoxified seed cake (1.76 g water/g protein) was similar to that reported by several studies [14-18], which indicate that this protein isolate had good water binding capacity possibly due to the interactions between polar amino acid residues of protein and water molecules. However, its water binding capacity was much lower than that of protein isolated from the seed cake without detoxification [8], since ethanol 
extraction might disrupt the internal structure and change the protein conformation, surface polarity and surface hydrophobicity of the protein in the seed cake.

Figure 1. Effect of $\mathrm{pH}$ on the solubility of the protein isolated from detoxified J. curcas seed cake.

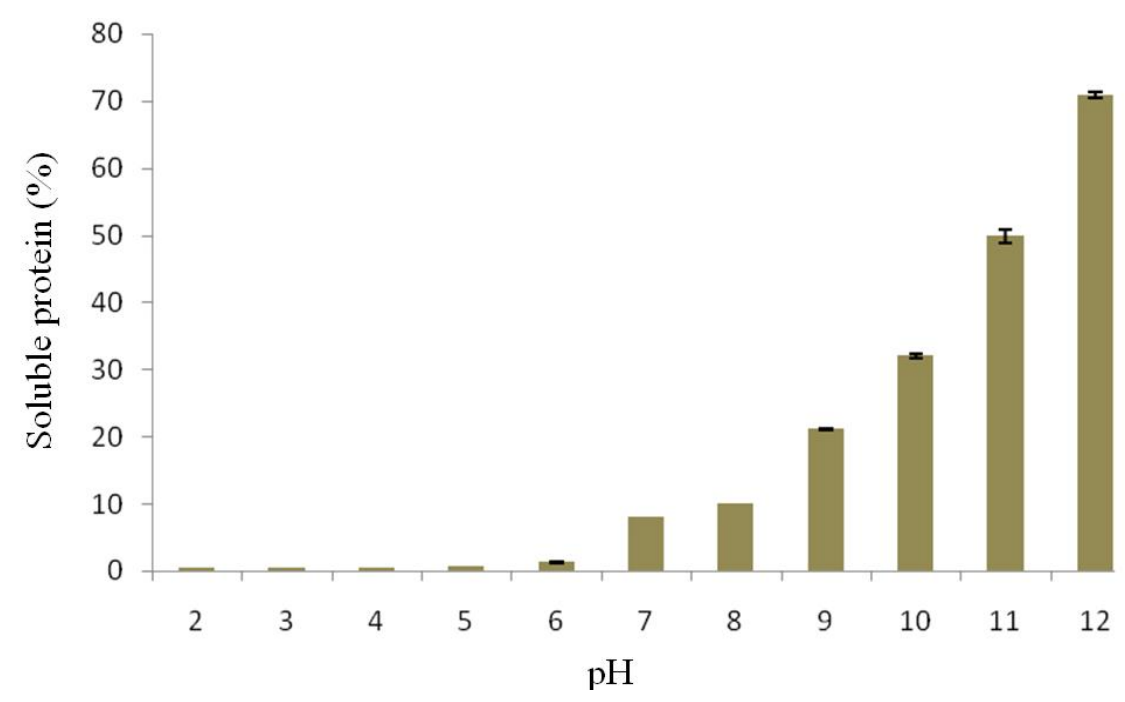

Oil binding capacity is another important functional property of proteins in food systems. It is a critical property of flavor retention. The oil binding capacity of the protein isolated from the detoxified seed cake was found to be $1.07 \mathrm{~mL}$ oil/g protein. It was lower than that of the protein isolated from the seed cake without detoxification $(1.86 \mathrm{~mL}$ oil/g protein) [8], cowpea protein isolates (2.0-2.22 $\mathrm{mL}$ oil/g protein) [19] and soy protein isolate $(3.29 \mathrm{~mL}$ oil/g protein) [20]. The result suggests that the protein isolate had low non-polar amino acid contents to bind with hydrocarbon chains of lipids.

\subsubsection{Foam Capacity and Stability}

Factors affecting foam capacity and stability of proteins are the type of protein, degree of denaturation, $\mathrm{pH}$, temperature and whipping methods. Foam can be produced by whipping air into liquid quickly as much as possible. The foam capacity of protein isolated from the detoxified seed cake was $\mathrm{pH}$-dependent, as presented in Figure 2. The protein isolate showed low foam capacity values at a $\mathrm{pH}$ range of 4.0-6.0 and the foam capacity was maximized at $\mathrm{pH} 12.0$. The foam capacity values increased under basic $\mathrm{pH}$ conditions. The higher capacity values are due to an increase in protein solubility where soluble proteins can reduce surface tension at the interface between air bubbles and the surrounding liquid. The foam capacity of this protein isolate was similar to that of the protein isolated from the seed cake without detoxification [8] but was lower than that of proteins isolated from other seeds $[18,21]$. This result indicates that the major protein molecules of $J$. curcas may be globular proteins since they were difficult to denature at the surface of their molecules leading to low foam capacity values [22]. 
Figure 2. Effect of $\mathrm{pH}$ on foam capacity of protein isolated from detoxified J. curcas seed cake.

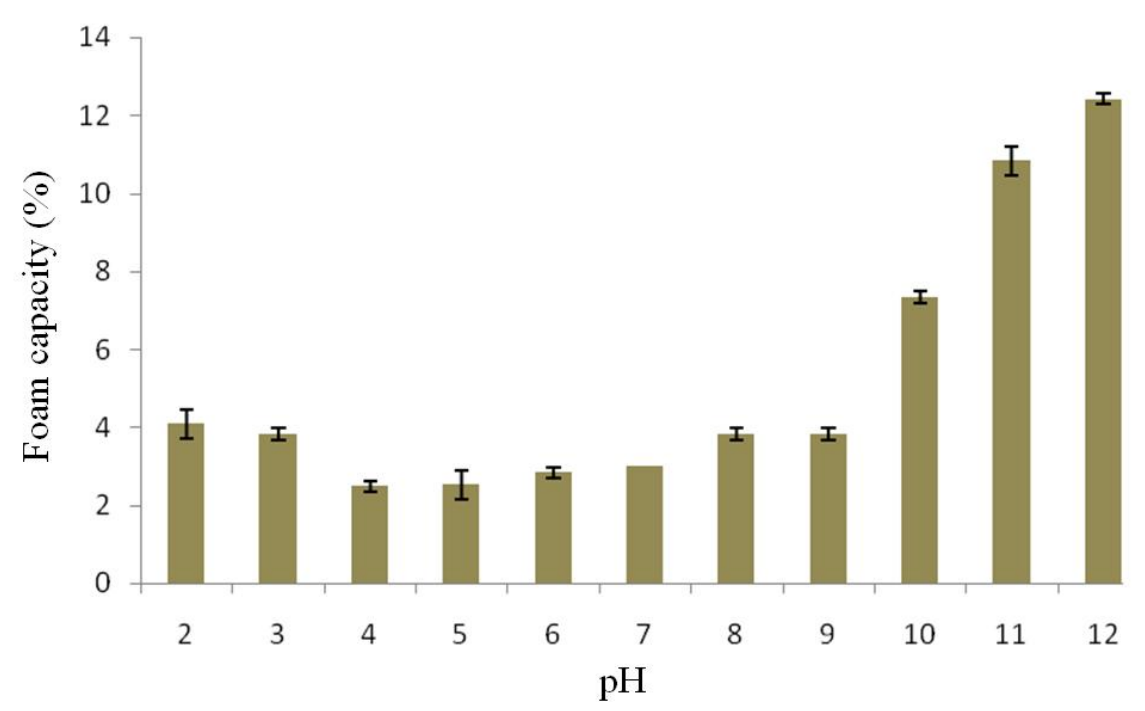

The effect of time and $\mathrm{pH}$ on the foam stability of the protein isolated from the detoxified seed cake is shown in Figure 3. The foam stability decreased with increasing time ranging from 15 to $60 \mathrm{~min}$. El-Nasri and El-Tinay [16] also reported a similar observation. The foam stability markedly decreased within the first $15 \mathrm{~min}$ and slightly decreased after $30 \mathrm{~min}$. The minimum stability of the protein isolate at the first $15 \mathrm{~min}$ was in a $\mathrm{pH}$ range of 4.0 to 6.0 (37-56\%). This result suggests that the interaction of protein-protein molecules at the isoelectric point leads to low foam stability values. The foam stability increased above and below the isoelectric $\mathrm{pH}$. The maximum foam stability of the protein isolate at the first 15 min was observed in a $\mathrm{pH}$ range of 9.0 to 12.0 (65-80\%). It was due to increasing protein solubility. After $60 \mathrm{~min}$, the low foam stability was observed in a $\mathrm{pH}$ range of 4.0 to 6.0 (9-12\%) and high stability was found between $\mathrm{pH}$ values of 10.0 to 12.0 (22-30\%). The overall foam stability of this protein was similar to that of the protein isolated from the seed cake without detoxification [8].

\subsubsection{Emulsion Activity and Stability}

Proteins generally possess hydrophobic and hydrophilic properties due to different types of amino acids. This causes protein interaction with both oil and water molecules and the proteins can act as emulsifiers. Emulsion capacity depends on the hydrophobic-hydrophilic balance, which is affected by $\mathrm{pH}$. The emulsion activity of protein isolated from detoxified $J$. curcas seed cake was pH-dependent as shown in Figure 4. The emulsion activity was low under acidic $\mathrm{pH}$ conditions, because proteins were low in solubility and lacked electrostatic repulsive forces which led to decreased emulsion formation. The emulsion activity of the protein isolate was found to be low in a $\mathrm{pH}$ range of 3.0-5.0. Its value increased with increasing $\mathrm{pH}$ and was maximal at $\mathrm{pH} 12.0$ due to the highest protein solubility. The emulsion activities of this protein at each $\mathrm{pH}$ were lower than those of the protein isolated from the seed cake without detoxification [8], which agreed well with their water and oil binding capacities. In addition, the emulsion activity of detoxified J. curcas seed cake at pH 12.0 was slightly different from that of fenugreek protein concentrate [16]. 
Figure 3. Effect of $\mathrm{pH}$ and time on foam stability of protein isolated from detoxified J. curcas seed cake.

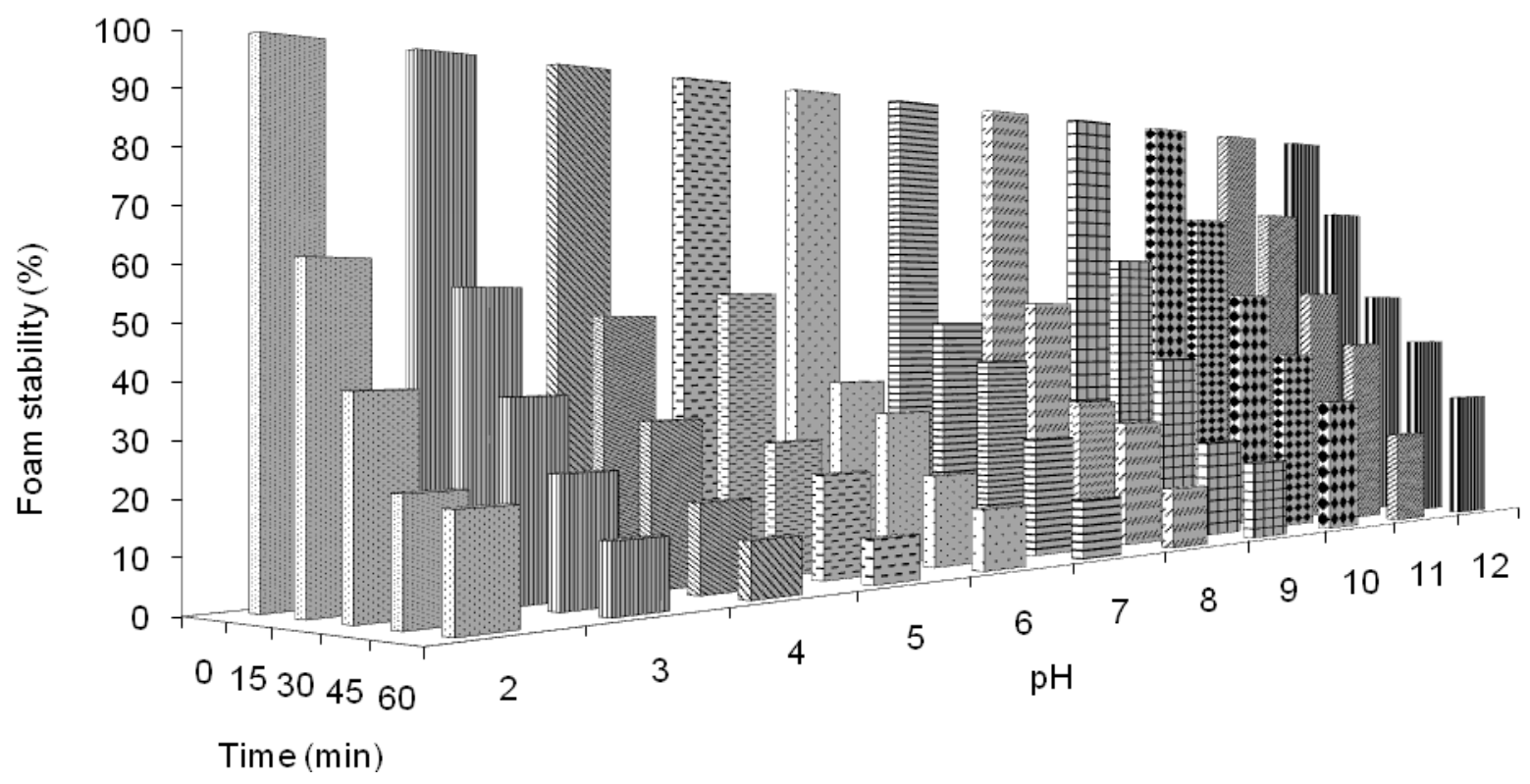

Figure 4. Effect of $\mathrm{pH}$ on emulsion activity of protein isolated from detoxified J. curcas seed cake.

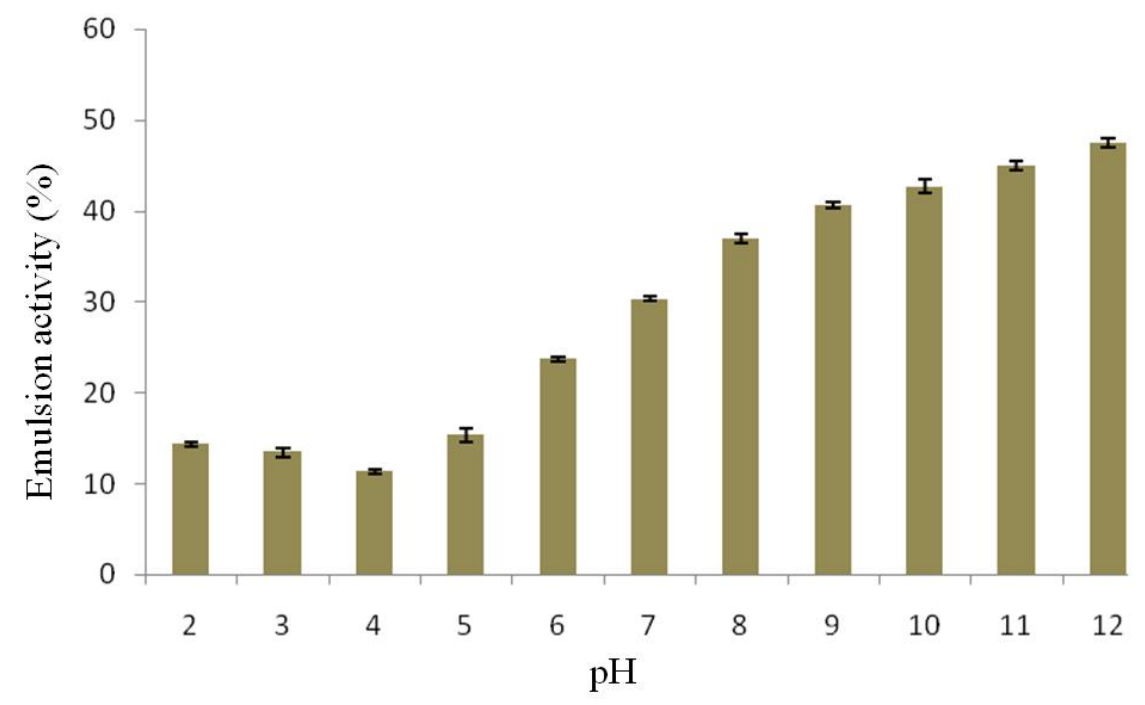

A suspension of protein isolate is generally heated in order to study its emulsion stability. This step leads to protein unfolding and the hydrophobic residues located inside the protein structure being exposed. This causes better adsorption of the protein molecules on an oil-water interface. The emulsion stability of protein isolated from the detoxified J. curcas seed cake was $\mathrm{pH}$ dependent (Figure 5). The emulsion stability was low under acidic $\mathrm{pH}$ conditions. The low emulsion stability at the isoelectric $\mathrm{pH}$ might be attributed to lack of electrostatic repulsive interactions among particles, which promotes flocculation and coalescence [23]. The emulsion stability of protein isolate was greatly different under basic $\mathrm{pH}$ conditions (8.0-12.0) and it was highest at $\mathrm{pH}$ 12.0. The emulsion stabilities of this protein at each $\mathrm{pH}$ were still lower than those of the protein isolated from the seed cake without 
detoxification [8], resulting from the change of protein conformation, surface polarity and surface hydrophobicity caused by ethanol extraction.

Figure 5. Effect of $\mathrm{pH}$ on emulsion stability of protein isolated from detoxified $J$. curcas seed cake.

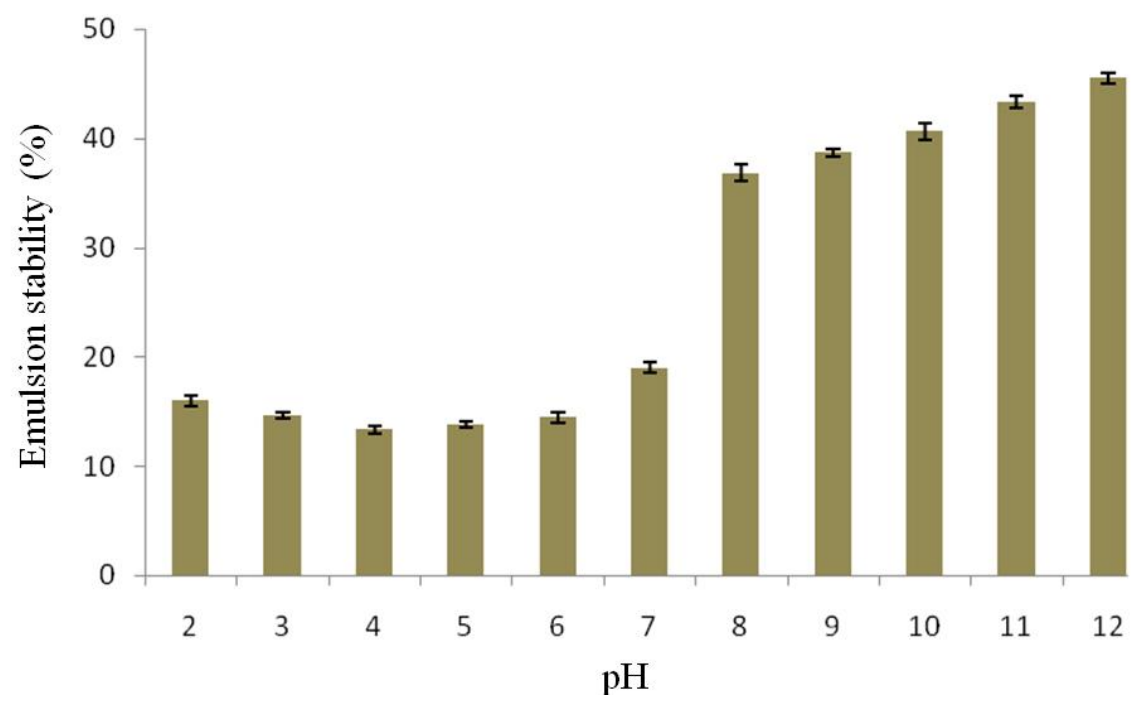

\section{Experimental Section}

\subsection{Material}

J. curcas seed cake was kindly provided from Ladda Company Limited. The whole seeds were pressed by a screw press and the oil was removed to obtain the seed cake. The seed cake was ground and packaged in polyester plastic bags. It was stored in a freezer at $-20{ }^{\circ} \mathrm{C}$ prior to use.

\subsection{Preparation of Detoxified J. curcas Seed Cake}

J. curcas seed cake was detoxified by ethanol extraction [24] in order to remove phorbol esters. Five grams of the seed cake was extracted by $15 \mathrm{~mL}$ of $90 \%(\mathrm{v} / \mathrm{v})$ ethanol with a shaking speed of $150 \mathrm{rpm}$ for $5 \mathrm{~min}$ at room temperature. This extraction was repeated four times. The seed cake passed through this process was referred to as the detoxified $J$. curcas seed cake.

\subsection{Preparation of Protein Isolates}

The detoxified $J$. curcas seed cake was suspended in distilled water (1:10). The $\mathrm{pH}$ of suspension was adjusted to 12.0 with $1 \mathrm{~N} \mathrm{NaOH}$ and stirred at $50{ }^{\circ} \mathrm{C}$ for $3 \mathrm{~h}$. Then, the suspension was centrifuged at $1837 \times \mathrm{g}$ (Rotanta 46R, Hettich, Germany) for $30 \mathrm{~min}$. The supernatant was collected and adjusted to $\mathrm{pH} 4.0$ with $1 \mathrm{~N} \mathrm{HCl}$ for protein precipitation. The precipitated proteins were collected by centrifugation and washed twice by distilled water and then dried by vacuum at $40{ }^{\circ} \mathrm{C}$. 


\subsection{Chemical Compositions}

Crude protein, crude lipid, crude fiber and crude ash contents of $J$. curcas seed cake, detoxified J. curcas seed cake and its protein isolate were determined according to the standard methods of the Association of Official Analytical Chemists (AOAC) [25]. Their available carbohydrate contents were calculated by difference. All analyses were performed in triplicate.

\subsection{Determination of Toxic Compound and Anti-Nutritional Factors}

Toxic compound and anti-nutritional factors of $J$. curcas seed cake, detoxified $J$. curcas seed cake and its protein isolate were analyzed.

Phorbol esters were extracted by the method of Saetae and Suntornsuk [24] and analyzed by HPLC according to the modified method of Hass and Mittelbach [26]. The analytical column was a Nova-Pak C18 column $(150 \times 3.9 \mathrm{~mm}$ i.d. and $4 \mu \mathrm{m}$ particle size, Waters $)$, with a SB-C18 guard column $\left(12.5 \times 4.6 \mathrm{~mm}\right.$ i.d. and $5 \mu \mathrm{m}$ particle size) (Agilent). The column was thermally controlled at $25^{\circ} \mathrm{C}$. A mixture of acetonitrile (HPLC grade, Fisher Scientific, Leicestershire, UK) and deionized water (80:20, v:v) was used as the mobile phase at a flow rate of $1 \mathrm{~mL} / \mathrm{min}$. The photodiode detector wavelength was set at $254 \mathrm{~nm}$. The phorbol 12-myristate 13-acetate (PMA) (Sigma Chemical) was used as an external standard.

Phytic acid was determined by a colorimetric method described by Vaintraub and Lapteva [27]. Results were expressed as \% (w/w) using phytic acid (sodium salt, Sigma Chemical) as a standard.

Trypsin inhibitor activity was determined by the method of Kakeda et al. [28] using benzoyl-DL-arginine-p-nitroanilide (BAPNA) as a substrate and porcine trypsin (Type II-S, Sigma Chemical). The result was expressed as trypsin inhibitor unit (TIU) per gram sample (detoxified seed cake or protein isolate).

Lectin activity was determined by the modified method of Gordon and Marquardt [29] by using hemagglutination assay.

Saponin content was determined by a spectrophotometric method described by Thilborg et al. [30]. The result was expressed as diosgenin equivalent from a standard curve of different concentrations of diosgenin (Sigma Chemical) in 80\% (w/v) aqueous methanol.

\subsection{Functional Properties of Protein Isolate}

Protein solubility was studied in the $\mathrm{pH}$ range of 2.0 to 12.0 . Protein isolate $(5 \mathrm{~g})$ for each $\mathrm{pH}$ was suspended in $20 \mathrm{~mL}$ of distilled water. The $\mathrm{pH}$ of the suspension was adjusted using $0.1 \mathrm{~N} \mathrm{HCl}$ or $0.1 \mathrm{~N} \mathrm{NaOH}$. The suspension was shaken for $1 \mathrm{~h}$ at $30{ }^{\circ} \mathrm{C}$ and centrifuged at $2000 \times \mathrm{g}$ for $30 \mathrm{~min}$. The protein content of the supernatant was determined by the method of Bradford [31]. Water and oil binding capacities were determined by the modified method of Beuchat [32] and Chakrabokry [33], respectively. Foam capacity and stability were determined by the modified method of Makri et al. [34]. Emulsion activity and stability were determined by the modified method of Naczk et al. [35]. 


\section{Conclusions}

Toxins and anti-nutritional factors in $J$. curcas seed cake could be totally or partially removed by ethanol extraction to leave a detoxified $J$. curcas seed cake. Protein isolated from the detoxified J. curcas seed cake showed high protein content (89\%). All functional properties of the protein isolate were observed to be good under neutral to basic $\mathrm{pH}$ conditions. Therefore, the protein isolated from the detoxified seed cake could be a good protein source for food systems since the protein contained no toxins and lectin. Studies in animal tests should be investigated to confirm the safety of protein isolated from the detoxified J. curcas seed cake before its applications into foods.

\section{Acknowledgements}

The authors would like to acknowledge the Thailand Research Fund (TRF) for a scholarship and financial support of D. Saetae under the Royal Golden Jubilee Ph.D. Program (Grant No. PHD/0062/2549). We also thank the Royal Thai Government for financial support through the Research Budget of KMUTT. We are grateful to the Ladda Company Limited for kindly providing J. curcas seed cake as the working material. Finally, we highly appreciate Michael Willing for his English proofreading.

\section{References}

1. Liberalino, A.A.A.; Bambirra, E.A.; Moraes-Santos, T.; Viera, E.C. Jatropha curcas L. seeds: chemical analysis and toxicity. Arq. Biol. Tecnol. 1988, 31, 539-550.

2. Makkar, H.P.S.; Becker, K.; Sporer, F.; Wink, M. Studies on nutritive potential and toxic constituents of different provenances of Jatropha curcas. J. Agric. Food Chem. 1997, 45, 3152-3157.

3. Makkar, H.P.S.; Aderibigbe, A.O.; Becker, K. Comparative evaluation of non-toxic and toxic varieties of Jatropha curcas for chemical composition, digestibility, protein degradability and toxic factors. Food Chem. 1998, 62, 207-215.

4. Martínez-Herrera, J.; Siddhuraju, P.; Francis, G.; Dávila-Ortíz, G.; Becker, K. Chemical composition, toxic/antimetabolic constituents and effects of different treatments on their levels in four provenances of Jatropha curcas L. from Mexico. Food Chem. 2006, 96, 80-89.

5. Aitken, A. The biochemical mechanism of action of phorbol esters. In Naturally Occurring Phorbol Esters; Evans, F.J., Ed.; CRC Press: Boca Raton, FL, USA, 1986; pp. 271-288.

6. Makkar, H.P.S.; Francis, G.; Becker, K. Protein concentrate from Jatropha curcas screw-pressed seed cake and toxic and antinutritional factors in protein concentrate. J. Sci. Food Agric. 2008, 88, 1542-1548.

7. Devappa, R.K.; Swamylingappa, B. Biochemical and nutritional evaluation of Jatropha protein isolate prepared by steam injection heating for reduction of toxic and anti-nutritional factors. J. Sci. Food Agric. 2008, 88, 911-919.

8. Saetae, D.; Kleekayai, T.; Jayasena, V.; Suntornsuk, W. Funtional properties of protein isolate obtained from physic nut (Jatropha curcas L.) seed cake. Food Sci. Biotechnol. 2011, in press. 
9. Abou-Arab, A.A.; Abu-Salem, F.M. Nutritional quality of Jatropha curcas seeds and effect of some physical and chemical treatments on their anti-nutritional factors. Afr. J. Food Sci. 2010, 4, 93-103.

10. Makkar, H.P.S.; Becker, K. Potential of Jatropha seed cake as protein supplement in livestock feed and constrains to its utilization. In Proceedings of the International Symposium on Biofuel and Industrial Products from Jatropha curcas and Other Tropical Oil Seed Plants, Managua, Nicaragua, 1997.

11. Idouraine, A.; Yensen, S.B.; Weber, C.W. Tepary bean flour albumin and globulin fractions, functional properties, compared with soy protein isolate. J. Food Sci. 1991, 56, 1316-1318.

12. Vani, B.; Zayas, F.J. Wheat germ protein flour solubility and water retention. J. Food Sci. 1995, 60, 845-848.

13. Mohamed, T.K.; Zhu, K.; Issoufou, A.; Fatmata, T.; Zhou, H. Functionality, in vitro digestibility and physicochemical properties of two varieties of defatted foxtail millet protein concentrates. Int. J. Mol. Sci. 2009, 10, 5224-5238.

14. Mansour, E.H.; Peredi, J.; Dworschak, E. Preparation and functional properties of rapeseed protein products. Acta Aliment. 1992, 21, 293-305.

15. Cheng, J.; Zhou, S.; Wu, D.; Chen, J.; Liu, D.; Ye, X. Bayberry (Myrica rubra Sieb. et Zucc.) kernel: a new protein source. Food Chem. 2009, 112, 469-473.

16. El-Nasri, N.A.; El-Tinay, A.H. Functional properties of fenugreek (Trigonella foenum graecum) protein concentrate. Food Chem. 2007, 103, 582-589.

17. Abdel-Aal, E.S.M.; Shehata, A.A.; Mahdy, E.A.R.; Youssef, M.M. Extractability and functional properties of some legume proteins isolated by three methods. J. Sci. Food Agric. 1986, 37, 553-559.

18. Sathe, S.K.; Deshpande, S.S.; Salunkhe, D.K. Functional properties of lupin seeds (Lupinus mutabilis) proteins and protein concentrates. J. Food Sci. 1982, 47, 491-497.

19. Sefa-Dedeh, S.; Yiadom-Farkye, N.A. Some functional characteristics of cowpea (Vigna unguiculata), bambara beans (Voandzeia subterranean) and their products. Can. Inst. Food Sci. Technol. J. 1988, 21, 266-270.

20. Mwasaru, A.M.; Muhammad, K.; Bakar, J.; Cheman, Y.B. Effect of isolation technique and conditions on the extractability, physiochemical and functional properties of pigeon pea (Cajanus cajan) and cow pea (Vigna unguiculata) protein isolates. II. Functional properties. Food Chem. 1999, 67, 445-452.

21. Akintayo, E.T.; Oshodi, A.A.; Esuoso, K.O. Effects of $\mathrm{NaCl}$, ionic strength and $\mathrm{pH}$ on the foaming and gelation of pigeon pea (Cajanus cajan) protein concentrates. Food Chem. 1999, 66, 51-56.

22. Sathe, S.K.; Deshpande, S.S.; Salunkhe, D.K. Functional properties of winged bean [Psophocarpus tetragonolobus (L.) DC] proteins. J. Food Sci. 1982, 47, 503-509.

23. Lawal, O.S. Functionality of African locust bean (Parkia biglobossa) protein isolate: effects of $\mathrm{pH}$, ionic strength and various protein concentrations. Food Chem. 2004, 86, 345-355.

24. Saetae, D.; Suntornsuk, W. Antifungal Activities of Ethanolic Extract from Jatropha curcas Seed Cake. J. Microbiol. Biotechnol. 2010, 20, 319-324. 
25. AOAC. Official Methods of Analysis, 16th ed.; Association of Official Analytical Chemists: Arlington, VA, USA, 1995.

26. Hass, W.; Mittelbach, M. Detoxification experiments with the seed oil from Jatropha curcas L. Ind. Crops Prod. 2000, 12, 111-118.

27. Vaintraub, I.A.; Lapteva, N.A. A modified method for the indirect quantitative analysis of phytate in foodstuffs. Anal. Biochem. 1995, 225, 206-212.

28. Kakade, M.L.; Rackis, J.J.; McGhee, J.E.; Puski, G. Determination of trypsin inhibitor activity of soy products: a collaborative analysis of an improved procedure. Cereal Chem. 1974, 51, 376-382.

29. Gordon, J.A.; Marquardt, M.D. Factors affecting hemagglutination by concanavalin A and soybean agglutinin. Biochim. Biophys. Acta 1974, 332, 136-144.

30. Thilborg, S.T.; Christensen, S.B.; Comett, C.; Olsen, C.E.; Lemmich, E. Molluscicidal saponins from a Zimbabwean strain of Phytolacca dodecandra. Phytochemistry 1994, 36, 753-759.

31. Bradford, M.M. A rapid and sensitive for the quantitation of microgram quantitites of protein utilizing the principle of protein-dye binding. Anal. Biochem. 1976, 72, 248-254.

32. Beuchat, L.R. Functional and electrophoretic characteristics of succinylated peanut flour proteins. J. Agric. Food Chem. 1977, 25, 258-261.

33. Chakraborty, P. Coconut protein isolate by ultrafiltration. In Food Engineering and Process Applications; LeMeguer, M., Jelen, P., Eds.; Elsevier Applied Science Publishers: New York, NY, USA, 1986; Volume 2, pp. 308-315.

34. Makri, E.; Papalamprou, E.; Doxastakis, G. Study of functional properties of seed storage proteins from indigenous European legume crops (lupin, pea, broad bean) in admixture with polysaccharides. Food Hydrocoll. 2005, 19, 583-594.

35. Naczk, M.; Diosady, L.L.; Rubin, L.J. Functional properties of canola meals produced by a two phase solvent extraction system. J. Food Sci. 1985, 50, 1685-1692.

(C) 2010 by the authors; licensee MDPI, Basel, Switzerland. This article is an open access article distributed under the terms and conditions of the Creative Commons Attribution license (http://creativecommons.org/licenses/by/3.0/). 